\title{
The Critical Discourse Analysis on Novel Sabtu Bersama Bapak by Adhitya Mulya
}

\author{
$1^{\text {st }}$ Bagus Ardiyansyah* \\ Postgraduate Sociology \\ Sebelas Maret University \\ Surakarta, Indonesia \\ bagus.ardiyansyah02@student.uns.ac.id \\ $4^{\text {th }}$ A. A. Chintya Maharani Putri \\ Postgraduate Sociology \\ Gadjah Mada University \\ Yogyakarta, Indonesia \\ aa.chintya.mp@mail.ugm.ac.id
}

\author{
$2^{\text {nd }}$ Drajat Tri Kartono \\ Postgraduate Sociology \\ Sebelas Maret University \\ Surakarta, Indonesia \\ drajattri@staff.uns.ac.id \\ $5^{\text {th }}$ Yeni Marcelawati \\ Postgraduate Sociology \\ Gadjah Mada University \\ Yogyakarta, Indonesia \\ ymarcelawati@gmail.com
}

\author{
$3^{\text {rd }}$ Argyo Demartoto \\ Postgraduate Sociology \\ Sebelas Maret University \\ Surakarta, Indonesia \\ argyodemartoto@staff.uns.ac.id
}

\begin{abstract}
This article aims to discuss an interesting phenomenon described in literacy media, the parts of fathers or man's image in the narrative or story of the novel Sabtu Bersama Bapak (Saturday Together with Father) by Adhitya Mulya. This article uses the critical discourse analysis method from Norman Fairclough, such as text analysis with an analysis of patriarchal culture from Sylvia Walby. Further, the dominant father's image is manifested from up to regulate the survival of all members of his family even though he (father) has died. Based on this, through the consumption of the text, namely the viewpoint of the researcher himself, the story in this novel represents a patriarchal ideology. The view of the image of men as the master of power and the image of women as controlled, in general, described in this novel through the position of wife and child in the dominance of patriarchal ideology.
\end{abstract}

Keywords—gender, media, critical discourse analysis, the culture of patriarchy.

\section{INTRODUCTION}

Language has a significant role for humans as a means of interaction-communication or socialization-in everyday life by assembling and creating sounds that gave rise to the concept, objects, and ideas. According to Kurniawan [1], human language is can express ideas, thoughts, opinions, news, thoughts, desires, feelings, and so forth to others. Helmet Peukert [2], a German thinker, said, "people can change the situation in the world precisely because he is a creature who speaks" (read: language). On development, written language stands out as a means of expressing the ideas, thoughts, and ideas man who is still in use. This can be seen, among other scientific works, in the form of papers, journals, literary works, newspapers, and so forth [3]. Speaking literary happenings, then literature is a form of creative art activity results and complexity human life object that uses the language as the intermediary [4]. Language is a literary raw material, like stone and copper, sculpture, paint for painting, tobacco for cigarettes, and so on [5]. Literature is a means for guiding, directing something about the kindness that has been seen, felt, and comprehensive manner contemplated by humans about life exquisitely presented and attractive, it can even affect cognitive and social action. Then literature is a form of creative art activity results and complexity human life object that uses the language as the intermediary. Language is a literary raw material, like stone and copper, sculpture, paint for painting, tobacco for cigarettes, and so on. Literature is a means for guiding, directing something about the kindness that has been seen, felt, and comprehensive manner contemplated by humans about life exquisitely presented and attractive, it can even affect cognitive and social action. Then literature is a form of creative art activity results and complexity human life object that uses the language as the intermediary. Language is a literary raw materials, like stone and copper, sculpture, paint for painting, tobacco for cigarettes, and so on. Literature is a means for guiding, directing something about the kindness that has been seen, felt, and comprehensive manner contemplated by humans about life exquisitely presented and attractive, it can even affect cognitive and social action.

The literary work is present amid of people's lives as a reflection of the social phenomena around which comes from the imagination of the author or creator. The author expresses human life and its response to the world by creating works of literature. Understanding literature as the article cannot be avoided, because literature itself etymologically means writing [6]. Many significant lessons that we can get from a literary work, such as a portrait understanding of human life. On the other hand, the author invites the reader to participate in solving the problems of life. According to Wellek and Warren, they believe in the notion of literature as an innovative works, imaginative and fictitious.

In the contemporary era, the novel is a form of literature, experiencing rapid development. It was able to happen because the novel can give joy and the inner satisfaction, moreover, from the children to adults, much like a novel. As a form of literature, the novel is the reality of the universe in which the events took place as well as experienced and practiced behavior of humans (figure). According to Hypollite Taine [7], it is a novel analog of small mirrors that can be taken anywhere, matching mirror to reflect all aspects of life and nature. The novel is a combination of fact, imagination, and idealism. Fictitious life (imagination) in a novel certainly cannot be separated from everyday social facts. In other words, the novel can visualize many aspects of life, including tragedy, happiness, disappointment, sadness, and even comedy. Insights can be increased or expanded readers through reading novels. Undeniably, everyone, no 
matter what their profession, will certainly do the activity of reading, including reading a novel.

This paper choses a novel by Adhitya Mulya. Adhitya Mulya is one of so many writers from Indonesia who was born on December 31977 , and is now married and has two sons. He is first known as the author of the novel through the Singles Comedy published in 2003, and it was adapted into film with a similar title. His most influential novel among other is his fifth novel, namely Sabtu Bersama Bapak [8].

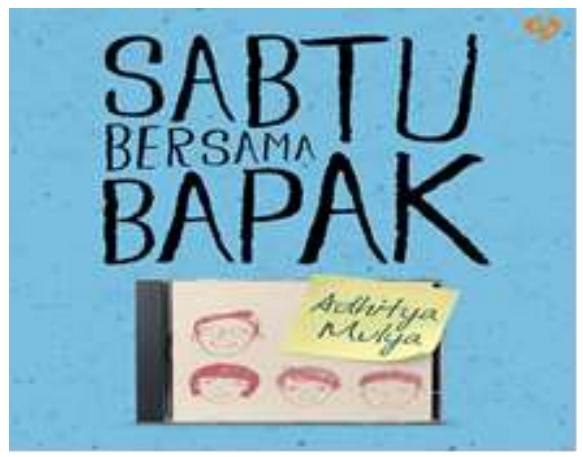

Fig 1: Cover of Sabtu Bersama Bapak

A novel of Sabtu Bersama Bapak consists of 277 pages, taking the background of everyday life and it is very touching in term of the family life. This novel tells the story of a small family Gunawan Garnida with his wife, Itje Garnida, and two children Satya Garnida and Chakra Garnida, also Rissa Wira Atmadja of Satya Garnida wife and their three children; Ryan, Miku, Dani, and Ayu Retnaningtyas, the future wife of Chakra Garnida. In addition, it is all about a story about a young man who learns to find love, about a man who learned to be a father and a good husband, a mother who took care of them with great affection, and the last is about a father who left a message and promised to always be with them.

Garnida Gunawan, a 38-year-old man and a householder who knew his life was no longer suffering from cancer, had passed various phases until it reaches the acceptance phase (reception). He will leave his wife (Itje), and two sons are still small. Although Gunawan will die, he still wants her children to survive and proceed through life with his guidance, especially as young with eight and five years old. Gunawan did not give a chance to the death to give distance and keep their children with a father figure. Therefore, before dying Gunawan make a video recording of messages and values (values) that he wanted to teach, Given the above description of the background, the researchers are interested in making novel of Sabtu Bersama Bapak as a research object because this novel clearly illustrates the severity of your love life and family life so that this novel became a best-selling national novel. On the one hand, as this novel rule out the role of women (mothers) in the process of socialization of children, which thus seemed to represent the ideology of patriarchy in it. Moreover, the power of the male figure to date in real or hidden, still so pronounced. With small nets and certainly, they spread and binding his authority, not only in the form of inanimate objects, but also in living organisms. Smooth confinement, so presumably is the case today, is no longer a real repression as formerly, and easily found in human smallest social unit, namely the family, although the pretext as an expression of affection, but affection in the mode of "having" in the version of Erich Fromm [9].

Furthermore, the discussion about this novel had previously been there that makes the object of study, but the study limited to the particulars of moral values as seen from an intrinsic element of the novel [10]. Then, the practice of patriarchal power that occurs in the world of literary language (like a novel) have there are several studies, including; in studies with novel object Trilogy Rara Mendut, Genduk Duku, and Lusi Lindri by YB. Mangunwijaya [11], a novel New Catatan Hati Seorang Istri by Asma Nadia [12], Representasi Ideologi Patriarki dalam Novel Sekuntum Ruh dalam Merah Karya Naning Pranoto [13], and others. Presumably, this is what led to researchers interested in reviewing further through the method of critical discourse analysis to show the text of patriarchal ideology contained in the novel Sabtu Bersama Bapak by Adhitya Mulya.

\section{THEORETICAL PERSPECTIVE}

There patriarchal culture in the whole world, not least in Indonesia. Positioning a patriarchal culture men superior to women in various sectors, both domestic and public. This hegemony the legitimacy of religion, social values, state law, and so forth are socialized from generation to generation [14]. Etymologically, patriarchy related to the social system in which the father mastered all the members of his family, his possessions, economic resources, and make all the important decisions, while literally, patriarchy is the power of the father or the patriarch. Patriarchy emerged as a form of men of higher social status than women, women must be mastered even as a male neighbor's goods [15]. According to Sylvia Walby [16], patriarchy is a social structure and practices where men dominate, oppress, and exploit women.

The practice of patriarchy can be started from the things that are not visible, such as language, the things around us, to penetrate novels, movies, and so forth. Furthermore, patriarchy can also be seen from the concept of Indonesia society, the position of women victims of violence. the position of women victims of violence. Often women victims of violence blamed (or co-blamed) for violence perpetrated by (male) offenders. For example, the wife of the victim of domestic violence by her husband blamed on the notion that domestic violence what the victim's husband did was a result her mistaken treatment of her husband. The victim's stigma is related to treatment (or service) to this husband has been putting the victim as bad as the perpetrator crime itself [17].

According to Sylvia Walby, patriarchy has two forms, namely domestic and public patriarchy. Domestic patriarchy based on male control of women individually and directly, for instance in the household. Work in the household is considered as the nature of women to be done, and its nature cannot be in the bargain, and the deprivation of women's work in families, such as child care jobs [18]. In domestic patriarchy, men who are in a position as a husband or father is an oppressor and control of family members, as well as a direct beneficiary of the subordination of women.

Public patriarchy is a form in which women have access, both in public and domestic arenas. Women are not prohibited in the public square, but still subordinate in it. Forms of exploitation of women takes place at all levels, but 
women are not formally excluded. As in the work, women earn less than men, women are concentrated in lower-level jobs (vertical segregation), also in a different work area (horizontal segregation). In addition to the jobs, public patriarchy another arena is the state. Stated in several previous studies, Walby continues that the public patriarchy in the country caused some impact, including: restrictions on women's access to jobs with wages; establish rules on marriage and divorce; criminalize forms of fertility control, for example, abortion and contraception; sexuality, with the birth of a court rules on a denial of child custody to lesbian mothers; criminalization of homosexuals; and male violence, with court actions primarily related to rape, sexual abuse, and sexual abuse.

Furthermore, television and other media, such as novels and others continue with this process (patriarchy). Television is an open resource for the community and continues to become more popular in the world. Television can make us interconnected albeit mediated, also show a film, advertising, and others that cannot be separated from the practice of ideology, including patriarchy [19]. As in advertising, usually featuring women when they are not as glamorous figure who was sexually then as housewives, while men occupy positions of power.

\section{METHODS}

In this study, to analyze practices and patriarchal domination, in the novel Sabtu Bersama Bapak by Adhitya Mulya, use the method of Critical Discourse Analysis of Norman Fairclough, in analysis text. Studies related to the theoretical study of literature and other references related to values, culture, and norms that develop in social situations were studied [20]. The method of critical discourse analysis used in the study because the focus of this research focuses on the content of the text in the novel [21]. At this stage of the analysis of texts (text analysis), locate or define the texts in the novel through dialogue or narrative that contains or contain elements of patriarchal ideology. This is because, in a text not only shows how an object depicted, but also how the relationship between objects defined generally contain a certain ideology load.

Furthermore, as Fairclough said, the language, text, or discourse is a depiction of social phenomena, which means there is a dialectical relationship between language and elements of social practice-this is the essence of Fairclough's approach, with assumptions that say that discourse is the most important form of social practice that reproduces and changes knowledge, identity, and social relations that include power relations as well as by other social structures and practices. In simple terms, able to explain various things that are not visible on the surface (implied or implicit). This means that Norman Fairclough's critical discourse analysis to uncover the interests and ideology that are implied behind each text or narrative. In other words, there is no neutral text considering that every language practice is never separated from the social, cultural, or ideological basis that surrounds it.

The stages of text analysis, examines formal features, such as vocabulary, grammar, syntax, and sentence coherence. Related to this, the text is everything that refers to writing, graphics, speech or speech, and a combination or all forms of text linguistics. In text analysis, the thing analyzed is the use of vocabulary related to certain meanings, use of terms, and metaphors because they refer to certain meanings or actions. A text can trigger conflicts, instruments of representation of something, and the like. The Fairclough text analysis includes a representation that is about something that wants to be displayed in the text, relations refer to how the construction of relationships between related parties, and the identity that leads to the construction and identity of related parties, also how personal or this identity is to be displayed. A text not only shows how an object is described, but also how relationships between objects are defined which generally carry a certain ideological content, because one word has many meanings and differs depending on the context [22]. In the context of this research, as in the text of novel Sabtu Bersama Bapak, the researcher will determine the texts in it which contain or represent elements of patriarchal culture, both in monologues, dialogues between characters, and narrative stories in related novels.

\section{RESULTS AND DISCUSSION}

\section{A. Analysis Text of Novel Sabtu Bersama Bapak}

TABLE 1: ANALYSIS TEXT OF NOVEL SABTU BERSAMA BAPAK

\begin{tabular}{|c|c|c|}
\hline $\begin{array}{l}\text { Discourse } \\
\text { Structure }\end{array}$ & Element & Identified Things \\
\hline \multirow[t]{3}{*}{ Representasion } & $\begin{array}{l}\text { Subordinate } \\
\text { clause }\end{array}$ & $\begin{array}{l}\text { 1. "you do not be afraid. I have } \\
\text { prepared everything" (page } \\
\text { 38) } \\
\text { 2. "All plans are in place" (page } \\
\text { 39). }\end{array}$ \\
\hline & $\begin{array}{l}\text { Combination } \\
\text { of clauses }\end{array}$ & $\begin{array}{l}\text { He has confirmed that there will be } \\
\text { enough instruments to make his } \\
\text { wife and children independent } \\
\text { without him. Insurance, passive } \\
\text { income, stocks, property, } \\
\text { everything makes it easy (page 30). }\end{array}$ \\
\hline & $\begin{array}{l}\text { Sentence } \\
\text { clusters }\end{array}$ & $\begin{array}{l}\text { "There are lots of their questions } \\
\text { later that I can't answer". } \\
\text { "No need." } \\
\text { "Let me answer their questions" } \\
\text { (page 39). }\end{array}$ \\
\hline
\end{tabular}




\begin{tabular}{|c|c|}
\hline Relation & $\begin{array}{l}\text { That his life is useful for others. He } \\
\text { believes that humans are placed in } \\
\text { the world to make this world better } \\
\text { for some others. Even if someone is } \\
\text { useful to } 1-2 \text { people, that person } \\
\text { has made this world a better place. } \\
\text { A thought that Ms. Itje can never } \\
\text { forget. It's her turn to make this } \\
\text { world better for others, no matter } \\
\text { how small the impact. Itje's mother } \\
\text { opened a rice shop in their } \\
\text { hometown, Bandung. Success. He } \\
\text { opened a second stall the following } \\
\text { year. His efforts are still facilitated. } \\
\text { Seeing the potential and building } \\
\text { detailed planning, Itje decided to } \\
\text { stop working in Jakarta, returning } \\
\text { to the Flower City (Bandung) to } \\
\text { develop this business. The result is } \\
\text { everything he has now. His little } \\
\text { rice stall has turned into eight } \\
\text { crowded restaurants with } 62 \\
\text { employees. Itje did not look } \\
\text { success of how much he monthly } \\
\text { income. He looked at the success of } \\
\text { how many jobs he created. And } \\
\text { make sure he doesn't become a } \\
\text { burden to his children. In } \\
\text { accordance with the husband's } \\
\text { message (page 30-31). }\end{array}$ \\
\hline Identity & $\begin{array}{l}\text { The episode at the beginning of } \\
\text { marriage teaches that the location } \\
\text { of each man are two steps in front } \\
\text { of the family he leads (page } 30 \text { ). }\end{array}$ \\
\hline
\end{tabular}

\section{B. Analysis of the Patriarchy Practice}

This section tells about the mother Itje the memories with her husband namely Gunawan Garnida before and after he passed away and left the fold of His family forever. According to his wife, her husband had prepared everything well. This can be seen in the sentences:

" "He has ensured that there will be enough instruments to make his wife and children independent without him. Insurance, passive income, stocks, property, all things make them not difficult"

The above text is a combination of clauses in the form of an extension, which is an extension clause of another clause. In this text, visible preparations that have been made by Gunawan Garnida meant for his family's future without the attendance figure later Gunawan beside them. All of this is done so that Garnida Gunawan family life is not difficult, his wife and children do not bother other people, and want to show that this family is a responsibility in the universe wherever he is.

Furthermore, the text above contains the meaning of patriarchal practices, which contain patriarchal cultural practices in the domestic sphere. The language used in the text above contains patriarchal cultural practices in the domestic realm, because it is seen from Gunawan that he has ensured that all the "instruments" that have been prepared will be sufficient and will make his family feel uncomfortable in the future. The prepared instrument shows
Gunawan's image as a protective man, guardian, responsible, controlling in his family, and indirectly has oppressed and subordinated women (Itje). These four images are a form of power, because power can be symbolized through protective men who are romantic and loving, and this has been illustrated in the actions that Gunawan has done in the name of his family's future.

January, December $24^{\text {th }} 1991$, there followed a conversation between the two of them, where Gunawan tried to make Itje not afraid to state his family later after his departure. Seen from the following sentence:

\section{"you do not be afraid. I have prepared everything"}

"All plans are in place"

Both of the above text is a fragment of dialogue that occurs between Gunawan with his wife Itje, the first text and the second is a representation clause in the form of the state, pointing to something that has happened. In the dialogue, describing fears or concerns Itje that will be left forever by Gunawan. However, Gunawan has prepared everything, both for the wife or his children. Furthermore, the above dialogue text fragment representing the patriarchal practices. Patriarchal cultural practices in the domestic domain also occurs in fragments of dialogue text above.

Gunawan described as the dominant figure as a man who is a husband and father had been controlling the lives of his family members, clever, knowing everything that is best for his family life in the future, and strong because it can prepare everything even in a state ill. Moreover, orders to Itje to live forward with her children by using "all plans" which have been prepared by Gunawan. As said Walby, patriarchy domestic boils down to the region of the household as the initial area of male power over women and other family members or men who are in a position as a husband or father is an oppressor and the direct beneficiaries of subordination of women. That said, these plans as a form of domination and control over his wife and children, his wife and children as objectivity on their husbands or fathers. Moreover, it is not directly give orders to Itje to live forward with her children by using "all plans" which have been prepared by Gunawan. As said Walby, patriarchy domestic boils down to the region of the household as the initial area of male power over women and other family members or men who are in a position as a husband or father is an oppressor and the direct beneficiaries of subordination of women.

The conversation between the two of them continued, Itje also said there was something else he could not do. In the following sentence:

"There are lots of their questions later that I can't answer".

"No need."

"Let me answer their questions."

The fragment of the dialogue text above is a representation of a series of intertallimals that shows the inability and weakness of a woman and highlights the ability of men over women. Factually, this reflects the real reality 
in everyday life and the writer re-illustrates the reality in the dialogue text section above. Deeper, explicitly the dialogue fragment above also contains patriarchal cultural practices in the domestic sphere. This can be seen from the meaning contained in the dialogue text above, that indirectly Gunawan as a husband or father is taking away or taking over the full role in educating his children and controlling their lives, thereby overriding Itje's role as a wife or mother, in other words concentration occurs to Gunawan. Although it was done as a form of affection from Gunawan, but love is a symbol of his power, because power can be symbolized through loving men. Patriarchal culture in the domestic realm is based on domination by men, concentration of men, and granting privileges to men so that men are in the position of husband or father who are oppressors, namely in the household (ie, in the household.

The phenomenon of subordinating or turning a woman into an inferiority position is again illustrated in the following sentence and the relation shown in this section is the closeness and obedience of the wife to her husband even the physical figure of the husband is no longer with the wife. In the following sentence:

"That his life is useful for others. He believes that humans are placed in the world to make this world better for some others. Even if someone is useful to 1-2 people, that person has made this world a better place. A thought that Ms. Itje can never forget. It's her turn to make this world better for others, no matter how small the impact. Itje's mother opened a rice shop in their hometown, Bandung. Success. He opened a second stall the following year. His efforts are still facilitated. Seeing the potential and building detailed planning, Ms. Itje decided to stop working in Jakarta, returning to Kembang City to develop this business. The result is everything he has now. His little rice stall has been transformed into eight crowded restaurants with 62 employees. Ms. Itje does not look at her success in terms of how much she earns per month. He looked at the success of how many jobs he created. And make sure he doesn't become a burden to his children. In accordance with the husband's message"

The sentence above describes the figure of Itje as a woman and wife who obeys all the words of her husband Gunawan Garnida. Factually, this phenomenon occurs in societies that have built households, the authors also describe the facts in the sentence above and want to convey that it is proper for women as a wife to be obedient and obey the words of her husband as long as these words contain a positive dimension so that each step contains blessings and accompanied by fluency.

Paradoxically, the above sentence implicitly contains patriarchal cultural practices in the public sphere. This can be seen from Itje's mindset and actions that are influenced by her husband's view of humans that are useful in the world. "She believes that humans are placed in the world to make this world better for some others. Even if someone is useful to one or two people, that person has made this world a better place. A thought that Ms. Itje can never forget. " Finally, it constructed Itje's thoughts about "useful people", then he quit his job in Jakarta and Itje established a successful food stall and then developed into eight food stalls with 62 employees. Itje's view of success is not income but from the number of jobs she has created, following her husband's view. The practice of public patriarchy in the sentence occurred because of the influence of her husband's views, making Itje open a food stall and quit her job in Jakarta. forms of exploitation such as in jobs where women earn less than men, also women are concentrated in lower jobs. The author places and illustrates Itje's lower position in work, despite having eight food stalls, this has not yet indicated Itje's position above her husband Gunawan Garnida.

The identity shown is representing the actions that must be done by men in terms of household, seen from the following sentence:

"The episode at the beginning of the marriage teaches that every man's location is two steps ahead of the family he leads."

In the sentence above, the writer wants to convey through his perspective as a man, using the metaphor "two steps ahead", that men as husbands and fathers must have thoughts, plans, and actions far ahead of their family members so that he is seen as a leader for his family. Furthermore, the above sentence contains patriarchal cultural practices in the domestic realm. It can be seen from the meaning in the sentence above which states that men as leaders in their families must be at the front and have the power to control the whole life of the family members. Although this is to show himself as a protective, guardian, and loving man, this is still a form of power, because power can be defined in terms of strength and control, also symbolized through romantic and loving protective men. In addition, it produces knowledge that women must be behind men. Domestic patriarchy is based on a man who controls women individually and directly, ie in the household, also men are in the position of husband or father who are oppressors and direct beneficiaries of female subordination.

\section{CONCLUSION}

This is like the public's view of the image of men as the holder of power, while women who are controlled. What is depicted in this novel, a hope that we want, especially the hope of children will be to obey all the moral advice from parents, an admiration. But in doing so, a phenomenon occurs beyond limitations or fairness. The business (men as husband and father), which imposes matrices of perception, thought, and all actions carried out by family members must be clearly in accordance with the inheritance of the 'discourse'. This vision is a proof of virility agents who want pleasure that is ensured through the form of obedience, on the basis of 'ownership' of the family which in fact is a praxis of affirmation of dominance in pure form. In its connotation, those actions are symbolic violence experienced by family members. A pleasure text (jouissance) that has been practiced by Adhitya Mulya, as said by Roland Barthes, so as to be able to make the general public or literary society become 'lovelorn' and addicted. Once again, that is the ambiguity that researchers try to 
accommodate, because on the one hand the 'pleasure' of the mass obtained through the abundance of texts, is a ritual of confirming the virility of all social and structural functions. A representation of mortality that creates a circulation of societal patterns to be like. This is called by McHale as "a blurring between the trustworthy and the can not be trusted".

\section{REFERENCES}

[1] Y. A. Darma, Analisis Wacana Kritis. Bandung: Yrama Widya, pp. 1. 2013.

[2] F. Borgias, Manusia Pengembara: Refleksi Filosofis tentang Manusia. Yogyakarta: Jalasutra. 2013.

[3] S. A. Maimunah, Bahasa Indonesia untuk Perguruan Tinggi. Malang: UIN-Maliki Press. 2011.

[4] A. Semi, Anatomi Sastra. Bandung: Angkasa Raya. 1993.

[5] R. Wellek and dan A. Warren, Teori Kesusastraan. Jakarta: PT. Gramedia Pustaka Utama. 2016.

[6] Faruk, Pengantar Sosiologi Sastra dari Strukturalisme Genetik sampai Post-Modernisme. Yogyakarta: Pustaka Pelajar. 2014.

[7] A. Anwar, Teori Sosial Sastra. Yogyakarta: Ombak. 2010

[8] N. Yuniar, Bincang-bincang Bersama Penulis Adhitya Mulya. Di dari http://antaranews.com/berita/544203 /bincang-bincang-bersamapenulis-adhitya-mulya. 2016

[9] E. Fromm,. Memiliki dan Menjadi: Tentang Dua Modus Eksistensi. Jakarta: LP3S. 1988.

[10] K. A. Dityasih, Nilai-nilai Moral dalam Novel Sabtu Bersama Bapak Karya Adhitya Mulya. Universitas Indonesia. 2015.

[11] R Dita, Pemberontakan Perempuan dalam Novel (Analisis Wacana Novel Trilogi Rara Mendut, Genduk Duku, dan Lusi Lindri Karya YB. Mangunwijaya). Tesis. Jurusan Ilmu Komunikasi Program Pascasarjana. Fakultas Ilmu Sosial dan Ilmu Politik. Universitas Indonesia. 2012.
[12] A. Utama and I. Juliawati, Ideologi Patriarki dalam Novel New Catatan Hati Seorang Istri Karya Asma Nadia dan Implikasinya Sebagai Bahan Ajar Sastra Indonesia di Sekolah Menengah Atas (SMA). Skripsi. Jurusan Pendidikan Bahasa dan Seni. Fakultas Keguruan dan Ilmu Pendidikan. Universitas Lampung. 2016.

[13] M. J. Munthe, Representasi Ideologi Patriarki dalam Novel Sekuntum Ruh Dalam Merah Karya Naning Pranoto (Kritik Sastra Feminis). Skripsi. Jurusan Pendidikan Bahasa dan Sastra Indonesia. Fakultas Pendidikan Bahasa dan Seni. Universitas Pendidikan Indonesia. 2014.

[14] M. Darwin, Maskulinitas: Posisi Laki-Laki dalam Masyarakat Patriarkis. Center for Population and Policy Studies Gadjah Mada University, pp. 281. 1999.

[15] A. K. Khotimah, Perlawanan Kaum Perempuan Terhadap Patriarki dalam Film: Analisis Wacana Perlawanan Kaum Perempuan Terhadap Patriarki dalam Film Perempuan Berkalung Sorban. Skripsi. Jurusan Ilmu Komunikasi. Fakultas Ilmu Sosial dan Ilmu Politik. Universitas Negeri Sebelas Maret. 2010.

[16] S. Walby, Teorisasi Patriarki. Yogyakarta: Jalasutra. 2014.

[17] S. Begum, Dominasi Budaya Patriarki dalam TransMedia Novel ke Game PC Ночhoѝ До3op (Nočnoj Dozor) 'Penjaga Malam'. Skripsi. Jurusan Sastra Rusia. Fakultas Ilmu Pengetahuan Budaya. Universitas Indonesia. 2012

[18] A. Omara, Perempuan, Budaya, Patriarki, dan Representasi. Mimbar Hukum, 2. 2004.

[19] C. Barker, Cultural Studies: Teori dan Praktik. Yogyakarta: Bentang. 2005.

[20] N. Fairclough, Discourse and Social Change. Cambridge: Polity Press. 1992.

[21] N Fairlough, Analysing Discourse: Textual Analysis for Social Research. London: Routledge. 2003.

[22] A. Mulya, Sabtu Bersama Bapak. Jakarta: GagasMedia. 2011. 